\title{
A tribute to Peter James (1930-2014)
}

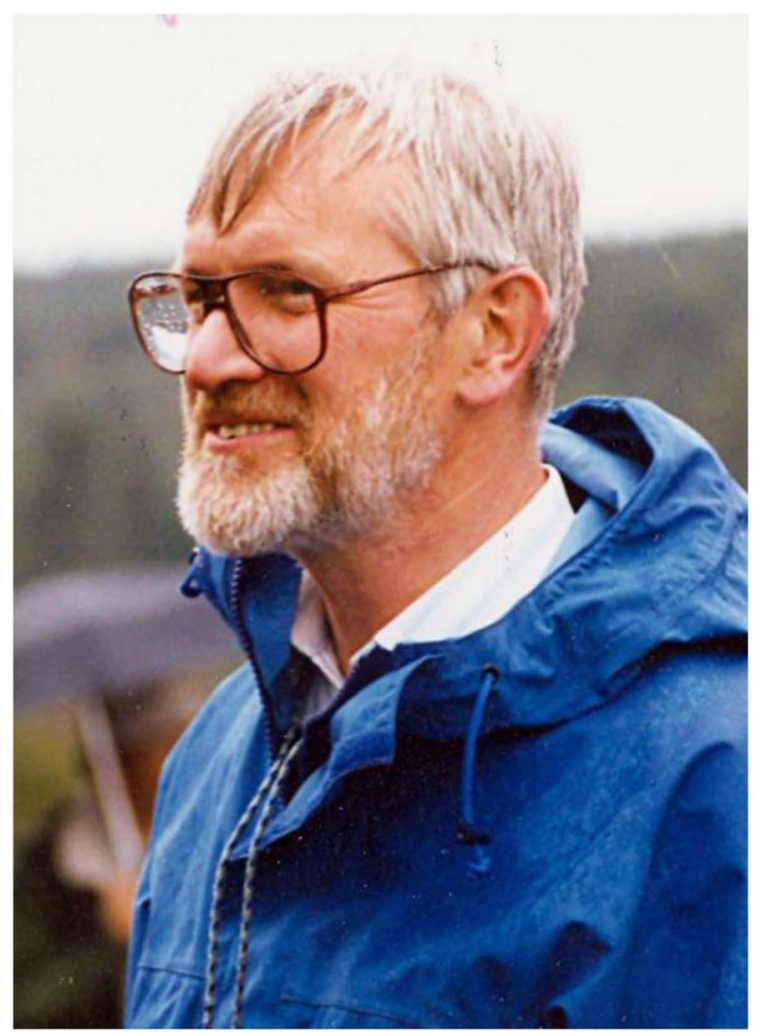

Peter James at IAL 2, Båstad, Sweden 1992 (Photograph Hannes Hertel)

On 13th February 2014, Peter Wilfrid James died aged 83. Many lichenologists throughout the world have lost a colleague and a friend who had assisted them in developing lichenology into the science that we know today (Galloway 2014a, b; Kärnefelt 2014; Marren 2014; Purvis et al. 2014). He played a key role in a worldwide network developing an understanding of lichens, the nature of their symbiosis, their taxonomy and their use as indicators of environmental change. Most of all he was a field botanist who took every opportunity to investigate lichens in their habitats as well as to teach others, amateurs and specialists alike.
Peter was born on 28th April 1930 and spent much of his early life in and around Sutton Coldfield in the British Midlands, where he acquired a passionate interest in natural history as well as an awareness of the problems created by atmospheric pollution and the intensification of agriculture, both subjects that he later developed at the Natural History Museum in London (NHM, better known under its Index Herbariorum abbreviation of $\mathrm{BM}$ ) and continued throughout his retirement. He returned to Sutton Coldfield when he retired in 1990 and resumed the sort of work that he had been renowned for: a field study on 
the lichens of Sutton Park, undertaken in collaboration with Mark Powell. Sutton Park was the setting for a gathering in April 2010 of Peter's close friends and colleagues to celebrate his 80 th birthday and the publication of this work, 45 years after his first paper on the topic (Field \& James 1965; James \& Powell 2010).

Peter James spent his entire working life at the Natural History Museum from 1955 to 1990, an unusual situation these days. On starting his job as Scientific Officer in what was then the British Museum (Natural History), he was immediately called up for National Service in the armed forces (1955-1957) with the 12th Royal Signals Squadron. He was stationed in Bavaria, where he made contact with Josef Poelt, the colossus of central European lichenology, and his student Hannes Hertel, resulting in productive and long-term friendships. Returning to the Museum in 1957, he was active on all fronts, setting up the framework in which lichenologists work today. With a small group of people, the British Lichen Society (BLS) was founded at the Museum in 1958. By 1960 the Society had almost 200 members. The list of new members in Volume 1 of The Lichenologist shows that 24 of the 41 new members were from abroad, a trend that remains the same today. Peter was editor, recorder (1958-1978) and president, and oversaw the evolution of The Lichenologist into a truly international publication and the principal outlet for lichen research. The time was right for this resurgence in lichenology, and there were willing collaborators across the world who wanted to participate. He was one of the founders of the IAL (International Association for Lichenology) and became its first president in 1969 at the International Botanical Congress in Seattle, serving in that role until 1975 (Arvidsson 2012). The museum archives on Peter (1966-90) are full of correspondence from and to lichenologists across the world, attesting to the rapid development of lichenology at this time, the problems encountered and methods being developed to aid the taxonomy of these symbiotic organisms.
After his return to the Museum in 1957, Peter travelled widely, often being away for months at a time, and never passing up an opportunity to explore another region for its lichens. His travels took him from the frozen southern limits of the world to the tropics, and from deserts to the temperate forests of the Southern Hemisphere. In Britain he travelled widely too and worked in remote sites, yet he never drove a car. His first major expedition abroad was with the Eric Shipton expedition to Patagonia in 1958-59, organized by the Tasmanian mountaineer and chemist, Geoff Bratt, then based at Imperial College London (Galloway 2014a, b). This was a formative period for Peter observing and collecting in many different environments, from the high Andes to deserts, temperate rainforest and pampas. Perhaps more significantly, it set him up as one of the few people in the world with a knowledge of the remarkable lichen flora of the temperate Southern Hemisphere, a role which developed in subsequent years and one which fostered a resurgence of lichenology in that region. He returned to the Museum almost six months later in April 1959, having collected 3905 specimens including more than 1500 lichens. The Museum received huge kudos from this expedition and in 1960 Peter was promoted to Senior Scientific Officer.

There was plenty to do when he returned. The Lichenologist was thriving and Peter was involved with research and curation, as his own job description in 1966 shows: "Writing and checking of scientific papers; nomenclatural work on lichens; lectures and study groups pertaining to group determination of world material; general curation; monographic studies; addition of material to collections." It was a seemingly impossible job. However, over time, the lichen section grew to include Jack Laundon (already working at the NHM since 1952) and additional staff. Those who became part of his team working on lichens included (at various times) Janet Menlove (Brinklow), Ian Tittley, Roy Vickery and Joy Walker (White), who contributed to the collections and research. In 1973, Robert Ross, Keeper 
of Botany 1966-1977, noted that: "He has been extremely successful in developing the talents of his staff and getting the best out of them. His one fault is that he tends to put requests for routine reports on one side and to need prodding to produce them!" A little later, John Cannon (Keeper of Botany 1977-1990) wrote, "There is no doubt that his first class work and very wide contacts reflect with considerable credit on the Museum as a whole, both in Britain and in the wider international community" (NHM archives). Peter was made Deputy Keeper of Botany in 1978, a post which he enjoyed but which brought new responsibilities and less time for research.

The impression of Peter as a lichenologist, sitting at his desk in the Museum editing and organizing, could not be further from the truth. Peter loved to be in the field and was a very able field botanist with a sharp eye for small and critical species. He demonstrated his perception of the "jizz" of the habitat repeatedly. For example, on a visit to western Norway, he recognized a certain kind of habitat and immediately started to look for rare species he knew from Britain, but which were unknown from Norway. On one occasion when he acted as the foreign examiner at a doctoral thesis in Bergen, he was taken to Milde where, on getting out of the car, he rushed to a nearby tree and found the rare Wadeana minuta Coppins \& P. James, new to Scandinavia, at its northern limit. It was growing on a tree that many lichenologists had passed by as being uninteresting. "Just the kind of tree it grows on in Britain", Peter remarked.

\section{Peter James as scientist}

Peter obtained a 1 st class honours degree in Botany at Liverpool University in 1952. He then commenced a PhD on epiphytes but unfortunately his supervisor died shortly afterwards. His new supervisor, knowing little about lichens, sent him to the Natural History Museum where he started curating the lichens so he could make use of them. The Museum realised his potential and he became a full-time museum staff member in
June 1955. His employment was interrupted by two years of National Service, but when he returned to work in 1957, he threw himself into the job and never completed his $\mathrm{PhD}$, like many others of his post-war generation. Within a short period of time, the Museum became the hub of a movement that changed lichenology across the world. First and foremost was the launch of the British Lichen Society in 1958, with a scientific journal devoted to lichens that became the most important way of circulating papers and ideas across the world. In October 1967, Rolf Santesson wrote to Peter to compliment him on the new checklist of British lichens (James 1965) and to say that, concerning The Lichenologist, "this journal has become an indispensable tool for lichenology" (NHM archives).

The checklist of British lichens (James 1965) was the precursor to the Introduction to British Lichens (Duncan \& James 1970), a modern 'flora' that served as a standard text for decades, not just in Britain but far afield. This descriptive approach continued throughout his life and was followed by the Lichen Flora of Great Britain and Ireland (Purvis et al. 1992) and, finally, the Lichens of Great Britain and Ireland (Smith et al. 2009), in which 1873 species in 327 genera are included in the 1046 pages. He did not use a computer and so when preparing the latter work, all descriptions and text were delivered or posted to Sutton Coldfield to be annotated with his neat, although often tantalizingly minute, handwriting adding useful notes, especially on field characters.

When Peter started working on lichens, there was very little interest in the photobiont in the UK. This was partly because this component of the lichen thallus was not easy to identify as its lichenized phenotypes do not often show diagnostically relevant characters, and even in culture remained taxonomically challenging. His meeting with Aino Henssen in 1971 led to a productive collaboration on cyanobacterial lichens, their joint research producing a monograph on the subantarctic genus Steinera (Henssen \& James 1982) and, more importantly, the pivotal and now classic paper on lichen 
cephalodia (James \& Henssen 1976) where it was shown that the mycobiont could support more than one type of photobiont and that the form of the thallus may change depending on the photobiont. The choice of photobiont and its biological and taxonomic importance occupied Peter for years, particularly in the disentangling of the taxonomy of the Lobariaceae and Pannariaceae.

Building on his connections with James Murray, an accomplished New Zealand lichenologist and chemist, Peter established a laboratory with thin-layer chromatography (TLC) facilities at the NHM (Galloway $2014 a, b)$, and was in contact with scientists who were developing new methods for the use of chemical characters as a taxonomic tool, including Chicita and Bill Culberson in the USA and Jack Elix in Australia.

Another important collaborative project at the Museum, undertaken with co-authors Per Magnus Jørgensen (PMJ) from Bergen and Charlie Jarvis at the NHM, concerned the typification of lichen names from the Linnaean herbarium at Burlington House (Jørgensen et al. 1994). PMJ came on a sabbatical to the NHM as an honorary research fellow in 1992 and together they worked to revise the Linnaean lichen names. Notes by Peter on thin-layer chromatography and microscopic details of Linnean types were put to good use, the detailed studies and discussions often leading to renewed studies of specimens and old texts (Jarvis 2007). PMJ recalls how he would write the first draft which Peter then, with great accuracy, turned into good academic English which he nicknamed 'Jamesisms', and how he was given a Collins Thesaurus of English that he still uses and cherishes.

Peter's interest in monitoring lichen communities in response to changing environmental conditions became a reality following the setting up of the environmental unit at British Petroleum in 1970. This followed the Torrey Canyon oil spill in 1967 when the government and conservation agencies became aware of the huge potential environmental damage. In 1971, the oil terminal at Sullom Voe in the Shetlands was at the planning stage and the opportunity arose to use lichens as monitors of environmental change. Together with Bill Syratt, ecologist for BP's environmental unit, Peter established quadrats on lichen communities in 1976 that were monitored again in 1978, 1982 and again in 1986 (the data are in reports held at the NHM). Meanwhile Peter contributed to courses on biological monitoring for industrialists and, in 1975, organized a symposium on lichens as biological monitors of pollution, the first of its kind in Europe. This was just the start and a more research-based opportunity arose when the Nature Conservancy Council (NCC) became interested in assessing the effects of acid rain on sensitive lichen communities across the UK. Peter obtained a three-year contract to set up monitoring of the Lobarion in sites across the country from 1986-1989. However, with the breakup of the NCC and the loss of funding, the reports were written but no scientific papers were produced. This was a huge disappointment to Peter and revisiting some of the sites in 1990 highlighted the dramatic changes in occurrence and vitality of species of Lobaria in England in response to both atmospheric conditions and management (Wolseley \& James 2000). A further opportunity arose with the Centre for Ecology and Hydrology $(\mathrm{CEH})$ to establish biological monitoring of lichens in sites adjacent to the ammonia monitoring stations (Apis website: http://www. apis.ac.uk/overview/pollutants/overview_ NH3.htm). This project continued long after Peter retired and led to the development of monitoring methods for the assessment of atmospheric nitrogen compound concentrations (Wolseley et al. 2006; Sutton et al. 2009). In 1992, his lifetime achievements in lichenology were recognized at the 2nd meeting of the International Association for Lichenology by the awarding of the Acharius Medal.

\section{Peter as teacher, supervisor and examiner}

From 1958 onwards, Peter ran lichen courses for the Field Studies Council in centres across the country, as well as extra-mural courses for 
London University and workshops for the BLS on particular groups of lichens. The last, for which he would produce an Aide Mémoire illustrated with character sketches, were hugely popular with lichenologists at home and abroad; the Aide Mémoire for the genus Usnea is still available from the BLS (James 2002). These courses were also the foundation for the growing public interest in lichens and air quality, as demonstrated whilst travelling to Zurich to attend the LICONS meeting in 1999. When asked by the air hostess what he did, Peter said that he worked on lichens. She replied "you mean those organisms that tell us about air quality"!

Perhaps Peter James' greatest contribution to lichenology was in training a new generation: supervising $\mathrm{PhDs}$ and examining others on a range of subjects including taxonomy, ecology and physiology which often led to long-term collaborations. One of the authors' experience (GK) is probably typical of the way Peter forged these relationships. Australian lichenology was experiencing a resurgence in the early 1980s, and although David Galloway was already working on his Flora of New Zealand Lichens under Peter's wing in London, the series of papers elucidating one group after another that preceded this book were just starting to appear. Peter was widely acknowledged as the undisputed master of Southern Hemisphere groups. A letter to him in early 1980, suggesting duplicate specimens for $\mathrm{BM}$ in exchange for some identifications, was quickly acknowledged. This blossomed into regular correspondence and a flow (at times a flood) of questions and specimens from Tasmania to London, and names, suggestions, comments on specific characters and a wealth of other data coming back. It was a correspondence not unlike that of the early Tasmanian colonial botanists who corresponded with the Hookers at Kew in the mid-19th century.

It is no exaggeration that Peter mentored and nurtured this aspiring, but totally untrained and inexperienced, student to a career in lichenology. The story was repeated several times over for others. The difference in this case was distance, and that all tuition was conducted by handwritten letters, typically on the now defunct blue aerogrammes. Also, there was no other locally-based supervisor involved. Peter had first visited Tasmania in 1963, but this new 'Tasmanian project' brought him back to that distant island twice more: in 1981 to get things started, and then in 1984 to oversee the commencement of writing up. In both cases, much of the time was spent in the field, collecting by day, sorting and dividing specimens by night, and the ritual concluded with a vigorous game of cards. He instilled many key principles over that time: that good taxonomy begins in the field, the importance of accurate observation and recording, the importance of supporting observations with herbarium specimens, and that sound taxonomy is based on studies of type specimens. The hundreds, if not thousands, of specimens that emanated from this relationship remain a critical scientific resource in the herbaria of London, Tasmania and elsewhere.

Today, in hindsight, it is easy to romanticize the teacher-student relationship with Peter James, especially as his interest in the individual and their welfare was surely equal to his interest in the science. The relationship remained throughout subsequent decades, evolving into one of close friends, confidantes and colleagues. Yet the early years were often difficult and frustrating, especially as ever-greater Museum responsibilities were thrust upon him. He always had good intentions, and made many promises, but increasingly needed to be cajoled and demanded much patience. There were no faxes or emails, and all was conducted by mail with as long as a two week delivery time. $\mathrm{He}$ struggled to put pen to paper, but was outstanding as a co-author, editor or referee. Much later, when asked how on earth he had managed to juggle the demands of his job and of colleagues closer to home with the needs of someone on the other side of the world, he replied modestly "only by dint of hard work... and because it was worth it". Many of those who learned at his side appreciate this and know that the debt can only be repaid by their own hard work. His unstinting assistance 
to others is also often honoured with species described by colleagues who had worked closely with him, and the epithet 'james' is sprinkled through many floras, as well as marked by the genera famesiella Lücking, Faperwia Tønsberg, Faperviella Printzen and Peterjamesia D. Hawksworth (Hertel 2012).

Peter formally supervised relatively few PhD students and was very proud of them. Yet he actively assisted many others, stepping in where he felt his particular help was needed. Today, academia seemingly has no niche for the scientist without a $\mathrm{PhD}$, much less conceives of such a person supervising the theses of others. Peter James was such a man. He could well have pursued higher qualifications himself, but chose the qualifications of others as a source of satisfaction and personal achievement. Thus many of his publications were co-authored with those he helped, something that is particularly found in Australasia where he co-authored many papers with David Galloway and Gintaras Kantvilas. With the latter's Tasmanian project, Peter was pivotal in giving the fledgling study legitimacy, especially in the early years (Kantvilas et al. 1985; Kantvilas \& James 1987). He was particularly excited by the phytosociological classification of Tasmanian rainforest lichen communities (Kantvilas 1988), which in many ways mirrored his own pioneering studies on the topic in Britain (James et al. 1977) and those of another PhD student, Anthony Fletcher, on marine and maritime lichen communities, for whom Peter was an external supervisor.

$\mathrm{He}$ also fulfilled his role as foreign examiner a number of times, especially in Scandinavia where these occasions are a kind of academic theatre, Peter appearing as amiable as usual but in no way avoiding difficult questions that resulted in interesting discussions with the candidates. PMJ particularly remembers his characterization of Tor Tønsberg's thesis on sterile, sorediate and isidiate lichens: "This is a 'Cadillac' of a paper, but we need a 'Volkswagen'". This clearly shows his goal: to make lichenology generally available and applicable to ecological studies, in which he was also engaged.

\section{Peter James and conservation}

Peter was interested in conservation from an early age in his home area of Sutton Park, where he recorded plants and other organisms including moths. His concern for the changing countryside in Britain in response to air pollution and agriculture led to close involvement with naturalists such as Derek Ratcliffe, who was vice chair of the Nature Conservancy Council (NCC, established in 1973) and chief scientist from 1973. Following the demise of the NCC in 1991 and the hiving off of scientific research in conservation to the National Environment Research Council (NERC), Peter became a founder member of Plantlife, an NGO devoted to protecting plants and their habitats.

The background to the changes in the environmental agencies in Britain in the 1980-90s is well illustrated in the Museum archives by the correspondence between Ratcliffe, Duncan Poore and others, and Peter. At this time, Ratcliffe and others were establishing the scientific principles on which the designation of sites and their management was based. Peter was a member of the Advisory Committee on Science (ACOS) set up by Ratcliffe within the NCC, and was undertaking surveys across the UK together with Francis Rose. This work provided the basis for an NCC contract to the BLS to define important sites for epiphytic lichens (Fletcher et al. 1982) and terricolous lichens of heathlands (Fletcher et al. 1984). These reports formed the basis for site designations of conservation status and led to a further contract to establish long-term monitoring of the Lobarion, a lichen community that is highly sensitive to changes in air quality and environmental conditions. But the split and reorganization of the NCC into three country agencies in 1991 was associated with a move away from environmental science towards amenity access to the countryside, and the Lobarion project was one of the fatalities. The concern of the scientific community about the shift away from ecological research and the accompanying loss of specialist expertise on the agency staff is recorded in letters 
from Poore and Ratcliffe to Peter in the 1980s. From that time onwards, the subsequent agencies have depended on contracting specialists in to provide the data. Today, 23 years later, the BLS, with a grant from Natural England, is using members to assess changes in the distribution and condition of macrolichen indicator species in the Lobarion community, defined by James et al. (1977) using a relatively simple recording scheme.

Although Peter continued to support the agencies with specific lichen-related contracts, his interest was in the wider aspects of conservation and in establishing an organization that would work together with scientists and citizens to protect plants and their habitats across the UK. He was closely involved with Plantlife since its formation in 1988 and its launch at the Museum in 1989, with Jane Smart as its first director. Peter was a founder member and a trustee, and became vice chair in 1998, a position that he held until 2006. Education was close to his heart, as he recognized the growing gulf in taxonomic expertise in schools and universities. At Plantlife, he not only helped staff hone their skills in lichen and fungus identification, but led numerous training events for members of the public. His influence is reflected in Plantlife's concern for cryptogams today: they employ a lichen and bryophyte coordinator in England and a lower plants \& fungus specialist in Wales. However, Peter's role in Plantlife went well beyond his championing the importance of lichens. $\mathrm{He}$ is remembered by Jane Smart, Plantlife's first Chief Executive: "Peter was an inspiration and an unfailing source of advice not only on lichens (we were happy to introduce him as the world's greatest lichenologist) but also on other aspects of plant conservation - he had an excellent sense of the threats to plant species and habitats and the action needed to tackle them. More than this he was very wise with considerable expertise of human nature! Peter became a constant source of advice and help to me on most aspects of running the charity - not only at the foundation of the organization but throughout its development. He was sharp, perceptive and very funny which meant that many hours spent in his company were not only productive but great fun."

\section{Peter James and the collections at the Natural History Museum}

Peter's contribution to the lichen herbarium in the Natural History Museum is in the order of 30-50000 specimens. We have tried to make an estimate of the countries of origin and numbers that includes material in the not-yet-incorporated collections, as we feel that this is a huge resource for lichenologists in the future, as well as providing a capsule in time for places across the world from 1955 onwards. As not all specimens are databased, we have had to complement these numbers with data recorded on acquisition forms on a Museum database (Table 1). He collected throughout Britain, including the Channel Islands and the Scillies, and especially in Scotland over many years of the departmental project to describe and survey the flora of Mull. This last survey contributed c. 4000 lichen specimens to the collections, a significant part of a total number from Britain of c. 20000 specimens collected by Peter from this part of the world alone. Publications from these collections are mainly in reports and papers to the NCC and also in the volume of papers on Mull (James 1978).

By far the majority of specimens which are not fully incorporated are from his journeys abroad, which began with collections he made with Josef Poelt in 1956 while on National Service in Bavaria and Austria. This small collection of 150-200 specimens has never been worked on, partly because it was overtaken in the following year by the expedition to Patagonia, the Argentine pampas and Tierra del Fuego (see Galloway 2014a, b; Purvis et al. 2014) to collect lichens, bryophytes and flowering plants for the Museum. Much of this collection is identified to genus only and remains only partially processed, reflecting the difficulty of identifying and/or describing species from remote places that contain many taxa new to science. 
TABLE 1. Collections made by Peter fames in countries outside the UK.

\begin{tabular}{|c|c|c|c|}
\hline Country (area) & $\begin{array}{l}\text { Total no. of } \\
\text { specimens } \\
\text { collected }^{\star}\end{array}$ & $\begin{array}{c}\text { No. of batches of } \\
\text { unincorporated } \\
\text { material }^{\star \star}\end{array}$ & Years \\
\hline Germany \& Austria (Alps) & 200 & 9 & 1956 \\
\hline Argentina (Patagonia) & 1507 & 143 & $1958 / 9$ \\
\hline Ireland & $>758$ & 80 & $1961-1968$ \\
\hline New Zealand, Auckland Islands and Australia (Tasmania) & 10614 & 182 & $1962 / 3$ \\
\hline Scandinavia & 1390 & 4 & 1967 \\
\hline $\begin{array}{l}\text { USA \& Canada (Washington State, Olympia peninsula \& } \\
\text { Ontario) }\end{array}$ & 3943 & 29 & 1969 \\
\hline Sweden & 18 & 0 & 1970 \\
\hline France (Brittany) & 25 & 1 & 1970 \\
\hline Finland & $?$ & 22 & 1974 \\
\hline Antigua & $?(>73)$ & 8 & 1976 \\
\hline Ascension Islands & $?$ & 21 & 1976 \\
\hline Portugal (Azores, Algarve \& Madeira) & 3320 & 329 & $1976-1988$ \\
\hline Canada (Ellesmere \& Skraeling Is., Alexandra Fjord) & $?$ & 9 & 1979 \\
\hline Norway & 40 & 0 & 1979 \\
\hline Austria (Graz) & 40 & 0 & 1979 \\
\hline Spain (Canary Islands) & $?$ & 14 & 1980 \\
\hline USA (Hawaii) & 550 & 1 & 1981 \\
\hline Australia & 1500 & 112 & 1981,1984 \\
\hline Norway & 340 & 4 & 1982 \\
\hline Channel Islands & 948 & 27 & 1986 \\
\hline Italy & ? & 3 & 1986 \\
\hline Chile & 2500 & 34 & 1986 \\
\hline Mexico (Baja California) & 1410 & 10 & $1988 / 9$ \\
\hline USA (Virgin Islands) & $?$ & 8 & 1989 \\
\hline
\end{tabular}

Notes: ${ }^{\star}$ the first column includes total numbers collected, but not all collections were recorded in the archived documents; ${ }^{\star \star}$ the second column refers only to material that is not yet incorporated in the taxonomically arranged main collections at BM; figures refer to the number of batches and include on average 10-20 specimens each.

His personal connections with lichenologists in Australasia, and his visits there, also generated large collections for the Museum and for the host countries, as well as producing numerous collaborative publications. A Museum project in the Azores also ran from 1974 to 1994 , and produced a collection of papers on the taxonomy and ecology of species in the Atlantic Islands (e.g. Purvis \& James 1993; Purvis et al. 1994). Table 1 presents the approximate numbers of these collections, together with the number of batches of non-incorporated material from each country.

Peter made the rich and important herbarium at $\mathrm{BM}$ accessible to international lichenologists who arrived in a constant stream through the years. Some, like PMJ, spent longer periods as a Scientific Associate. Others included Ted Ahti (Finland), D. D. Awasthi (India), Ernie Brodo (Canada), Jack Elix (Australia), Edith Farkas (Hungary), Rex Filson (Australia), Mason Hale (USA), Aino Henssen (Germany), Hannes Hertel (Germany), Henry Imshaug (USA), Gintaras Kantvilas (Tasmania), Sergei Kondratyuk (Ukraine) and Cliff Smith (Hawaii), in addition to many British lichenologists who are now experts in their fields. Peter spent much time helping visitors, not only at the microscope or in the herbarium, but also socially by inviting them for lunch and evening entertainments such as concerts, or to his home at 19 Edith Road where he cooked the most 
delicious meals while playing records (often Bach, on whom Peter was an expert).

Together with collaborators, Peter described 148 new species, of which the Museum holds 57 holotypes. Following a type digitization project at the Museum, the data can now be consulted for images and protologues for c. $70 \%$ of the species (http:// plants.jstor.org/). Although he collected in many places abroad, the majority of types attributed to Peter James are named from British and European collections. A marked exception is Australasia, where he already had established collaborators in Galloway and Kantvilas. In the future, as collecting in many parts of the world becomes increasingly restricted, lichen collections made by Peter James from many, often remote, regions will be available for study in order to assess changes in diversity and environmental conditions, especially in places where the loss of both habitats and species is occurring at a great rate.

The authors thank the archivists at the Natural History Museum for providing access to many of the documents and letters, the volunteers who contributed to the assessment of the collections made by Peter James at the NHM, Aurelie Grall for her help with accessing the collection information available on the database at the Museum, Tim Wilkins (Plantlife) and Dr Jane Smart at IUCN in Switzerland for contributing material concerning Plantlife that was not available at NHM, and Brian Coppins for useful comments on the table and manuscript.

\section{REFERENCES}

Arvidsson, L. (2012) Presidents of the International Association for lichenology. Bibliotheca Lichenologica 108: $1-20$.

Duncan, U. K. \& James, P. W. (1970) Introduction to British Lichens. Arbroath: Buncle \& Co.

Field, J. C. W. \& James, P. W. (1965) Sutton Park: $A$ History and Guide. Sutton Coldfield: The Friends of the Park Association, The Sutton Coldfield News.

Fletcher, A., Coppins, B. J., Hawksworth, D. H., James, P. W. \& Rose, F. (1982) Survey and Assessment of Epiphytic Lichen Habitats. Report prepared by the Woodland Working Party of the British Lichen Society for the Nature Conservancy Council.

Fletcher, A., Coppins, B. J., Gilbert, O. L., James, P. W. \& Lambley, P. W. (1984) Survey and Assessment of Lowland Heathland Habitats. Report prepared by the Heathland Working Party of the British Lichen Society for the Nature Conservancy Council.

Galloway, D. J. (2014a) Peter Wilfrid James (1930-2014). The godfather of modern Australasian lichenology. Australasian Lichenology 75: 44-62.

Galloway, D. J. (2014b) Peter Wilfrid James (1930-2014): the Dunedin (New Zealand) connection, 1962-1963. British Lichen Society Bulletin 117: $17-31$.

Henssen, A. \& James, P. W. (1982) The lichen genus Steinera. Bulletin of the British Museum (Natural History) Botany 10: 227-256.

Hertel, H. (2012) Gattungseponyme bei Flechten und lichenocolen Pilzen. Bibliotheca Lichenologica 107: 1-157.

James, P. W. (1965) A new checklist of British lichens. Lichenologist 3: 95-153.

James, P. W. (1978) Lichens. In The Island of Mull, a Survey of its Flora and Environment (J. A. Crabbe \& A. C. Jermy, eds): 14.1-14.62. London: Natural History Museum Publications.

James, P. (2002) Aide Mémoire: Usnea. London: British Lichen Society.

James, P. W. \& Henssen, A. (1976) The morphological and taxonomic significance of cephalodia. In Lichenology: Progress and Problems (D. H. Brown, D. L. Hawksworth \& R. H. Bailey, eds): 27-77. London: Academic Press.

James, P. \& Powell, M. (2010) The lichens of Sutton Park, Warwickshire. British Lichen Society Bulletin 107: 2-17.

James, P. W., Hawksworth, D. L. \& Rose, F. (1977) Lichen communities in the British Isles: a preliminary conspectus. In Lichen Ecology (M. R. D. Seaward, ed.): 295-413. London: Academic Press.

Jarvis, C. E. (2007) Order Out of Chaos: Linnaean Plant Names and Their Types. London: Linnean Society of London, Natural History Museum.

Jørgensen, P. M., James, P. W. \& Jarvis, C. (1994) Linnaean lichen names and their typification. Botanical fournal of the Linnean Society 115: 261-405.

Kantvilas, G. (1988) Tasmanian rainforest lichen communities: a preliminary classification. Phytocoenologia 16: 391-428.

Kantvilas, G. \& James, P. W. (1987) The macrolichens of Tasmanian rainforest: key and notes. Lichenologist 19: $1-28$.

Kantvilas, G., James, P. W. \& Jarman, S. J. (1985) Macrolichens in Tasmanian rainforests. Lichenologist 17: 67-83.

Karnefelt, I. (2014) Every picture tells a story: Peter W. James (1930-2014). Graphis Scripta 26: 63-64.

Marren, P. (2014) Obituary in The Independent Sunday 30th March. http://www.independent. co.uk/news/obituaries/peter-james-lichenologist-whowas-one-of-the-first-to-establish-the-study-of-theseprimitive-plants-as-a-scientific-speciality-9224719. html

Purvis, O. W. \& James, P. W. (1993) Studies in the lichens of the Azores. Part 1 - Caldeira do Faial 
[Estudo dos líquenes dos Açores. Parte 1-Caldeira do Faial]. Arquipélago 11A: 1-15.

Purvis, O. W., Coppins, B. J., Hawksworth, D. L., James, P. W. \& Moore, D. M. (1992) The Lichen Flora of Great Britain and Ireland. London: Natural History Museum.

Purvis, O. W., Smith, C. W. \& James, P. W. (1994) Studies in the lichens of the Azores. Part 2 Lichens of the upper slopes of Pico Mountain. A comparison between the lichen floras of the Azores, Madeira and the Canary Islands at high altitudes. Arquipélago 12A: 35-50.

Purvis, O. W., Wolseley, P. A. \& Thüs, H. (2014) Peter Wilfrid James FLS (28 April 1930-13 February 2014): an appreciation. British Lichen Society Bulletin 117: 2-13.

Smith, C. W., Aptroot, A., Coppins, B. J., Fletcher, A., Gilbert, O. L., James, P. W. \& Wolseley, P. A. (2009) The Lichens of Great Britain and Ireland. London: British Lichen Society.
Sutton, M. A., Wolseley, P. A., Leith, I. D., Van Dijk, N., Tang, Y. S., James, P. W., Theobald, M. R. \& Whitfield, C. (2009) Estimation of the ammonia critical level for epiphytic lichens based on observations at farm, landscape and national scales. In Atmospheric Ammonia (M. A. Sutton, S. Reis \& S. M. H. Baker, eds): 71-86. Dordrecht: Springer.

Wolseley, P. \& James, P. (2000) Factors affecting changes in species of Lobaria in sites across Britain 1986-1998. Forest, Snow and Landscape Research 75: 319-338.

Wolseley, P. A., James, P. W., Theobald, M. R. \& Sutton, M. A. (2006) Detecting changes in epiphytic lichen communities at sites affected by atmospheric ammonia from agricultural sources. Lichenologist 38: 161-176.

Pat Wolseley, Per Magnus Jørgensen,
Gintaras Kantvilas and Holger Thüs 